\title{
Digital Storytelling Media by Paired Storytelling Model to Improve Speaking Skills
}

\author{
W. Ummah, Suhartono, B. Yulianto \\ Universitas Negeri Surabaya \\ Surabaya, Indonesia \\ wachidaummah13@gmail.com
}

\author{
M. N. Fahmi \\ STKIP Modern Ngawi \\ Ngawi, Indonesia \\ nahdifahmi91@gmail.com
}

\begin{abstract}
This research develops digital storytelling (DST) media with paired storytelling model. Specifically, this study aims to describe the process and quality of DST media development with a paired storytelling learning model to improve the speaking skills of grade II students of SDI Annur. This type of research is research and development. The research subjects were SDI Annur class II students. The data collection technique was through observation, interviews, questionnaires, and oral tests. Data analysis of the development process was carried out through descriptive techniques and to measure the quality of development was carried out through quantitative descriptive technique. Based on the results of the study, the validity of DST media obtained $89 \%$ with very valid criteria. The practicality of DST media gained $89,3 \%$ with very practical criteria. The effectiveness of DST media gained $85 \%$ with very effective criteria. So it can be concluded that the digital storytelling media developed by the researcher is considered very feasible as a medium to improve the speaking skills of second grade students of Annur Surabaya Islamic Elementary School.
\end{abstract}

Keywords-Digital storytelling media; Paired storytelling model; Speaking skill.

\section{INTRODUCTION}

Language is a means of communication with the aim of fulfilling the basic nature of the individual as a social being that requires interaction with its environment. A person who has adequate language skills will be easier to transform and convey information both orally and written. According to Anderson (in Tarigan, 2008: 1), language skills have four components: listening, speaking, reading and writing. Students must be able to master the four aspects of these skills in order to be skilled in the language.

Based on the results of observations and interviews on Thursday, January 15, 2018, it found that grade II students' speaking skills of SDI (Islamic Elementary School) Annur are low. The teacher stated that most of the students are less communicative in the form of oral.

The use of learning media is able to overcome any challenges and improve students' speaking skills, moreover when it is using digital storytelling (DST) media with paired storytelling model. Digital storytelling is a learning medium designed using a computer by combining the visualization aspects of animated images and sound effects of learning videos. Paired storytelling model is a model developed as an interactive approach between students, teaching and teaching materials.

The purpose of developing DST media with paired storytelling learning model is to improve the speaking skill of second grade students of Islamic Elementary School Annur.

The formulation of the research problem as follows: (1) How is the process of developing DST media with paired storytelling model can improve the speaking skill of second grade students of Islamic Elementary School Annur? (2) How is the quality of DST media with paired storytelling learning model can improve the speaking skill of second grade students of Islamic Elementary School Annur?

The significance of this study are: (1) Theoretically the results of this study can be used as a contribution to include the activities of educators' and students' activities as well as the value of speaking skills; (2) Practically a) For teachers: Teachers can use instructional DST media as a means of learning resources of Indonesian class II elementary school; Teachers can practice the paired storytelling model that can enhance the learning activity in the classroom; b) For Students: Students can improve their speaking skills; Students will be more motivated to follow the learning with DST media; Students will be more active in learning with paired storytelling model; c) For other Researchers: This research is expected to motivate other researchers to create learning media in accordance with the needs of students and technological developments. The process and results of this study are expected to be used as a input or reference in further research.

According to Tarigan (2008: 16), speaking skills are a form of language skills as the ability to say things related to sounds, pronunciation and words to express an opinion, 
thought, and idea orally either to a person or groups, either face to face or not. Therefore, speaking skills are important skills for elementary school students.

The paired storytelling model is one of the cooperative learning models developed by Lie (2010: 151). The paired storytelling model is a learning model that emphasizes the activities of working together between students with each other to achieve a goal.

\section{METHOD}

\section{A. Research Design}

This is a research and development or development research. The purpose of this research is to produce DST media with paired storytelling model to improve speaking skill in second grade students of Islamic elementary school. The development of DST media is to improve students' speaking skills using Four-D Model, defining; designing; developing and disseminating, proposed by Thiagarajan and Samuel. In this research the development of DST media is simplified only up to the development stage.

In the process of developing DST media, the distribution stage is not done because it is constrained by the time of the research, but this have produced the desired product stage of development process as follows. 1) The defining stage includes: (a) preliminary analysis, (b) student analysis; (c) task analysis; (d) conceptual analysis, and (e) the formulation of learning objectives. 2) The design stage includes: (a) selecting the DST media format, (b) designing the DST media (making draft I DST media), and (c) determining the DST media validator. 3) Development stage includes: (a) validation of DST media, (b) revision I, (c) trial I, (d) revision of trial I, (e) trial II, and (f) revision of trial II, and (g) revision III.

The quality of DST media with paired storytelling model can be measured from the level of its validity and effectiveness. The quality of DST media as follows. 1) The validity of DST media is measured through expert validator ratings. 4 validator lecturers perform an assessment of 4 components namely, the material component, language, sound and image. 2) The practicality of DST media applied using paired storytelling learning model is resolved through observation of RPP implementation, teacher response, and student response. 3) The effectiveness of DST media is measured through teacher activity observation, student activity enrichment and mastery of speech skill.

\section{B. Population and Sample}

The subject of this research are second grade students of Islamic Elementary School Annur, Surabaya, in the 2017-
2018 academic year. The subject was chosen because the school has applied the current revised 2013 curriculum. This class used as the trial of the media effectiveness, that consist of 10 students, 2 teachers. Additionally, as the validator of the media this research used 4 qualified lectures to do a validation on the produced media.

\section{Technique of Data Collection}

Data collection techniques of DST media process is based on the definition, design and development of DST media. The techniques used to collect process data are observations and interviews.

DST media quality data collection techniques are based on the validity, validity, and effectiveness of the media. The techniques used to collect quality data are questionnaires, observations and tests.

\section{RESEARCH RESULT}

\section{A. The Process of Developing Digital Media Storytelling with Paired Storytelling Model}

The process of developing DST media with learning paired storytelling model class II in the even semester is based on three stages in accordance with the Four-D development model, namely the defining, planning and development phase.

\section{1) Definition stage}

The defining stage includes, (a) preliminary analysis; (b) student analysis; (c) task analysis; (d) concept analysis; and (e) the formulation of learning objectives. Based on the results of the analysis, students are low in their speaking skill. Therefore, It is necessary to develop digital storytelling media with paired storytelling model that can improve students' speaking skill.

\section{2) Designing stage}

The defining stage includes a) Determining the learning objectives; b) Determining the content of the material in DST media that refers to the learning objectives. The content of the material in DST media is an animal fairy tale (fable) that describes a harmonious attitude of life; c) Designing a drawing images that will be presented in DST media with Adobe Photoshop; d) Making the story character catwalks in DST media. The characters are ducks, chickens, weasels and rats; e) Preparing a story script in DST media; f) Conducting voice recording and music that supporting DST video media. There are 5 dubbers in producing this media, they are Wakhidatul Ummah as narrator, Anis Maulidiyah as a duck, Muhammad Khoirul Mustofa as a chicken, Abdul Kholiq Al Anam as a weasel, M Luqhi as a mouse; g) Collaborating all rough digital material with the video application using wondershare video 
editor; h) Preparing a draft that is ready to be validated and applied in the lesson.

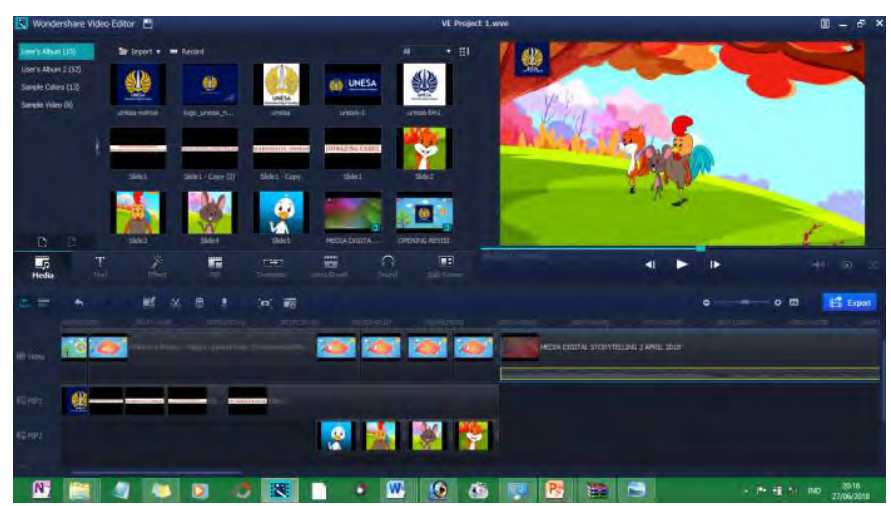

Fig. 1. Digital media storytelling design

\section{3) Development stage}

Development phase includes: (a) validation of DST media, (b) revision I, (c) trial I, (d) revision of trial I, (e) trial II, and (f) revision of trial II, g) revision III.

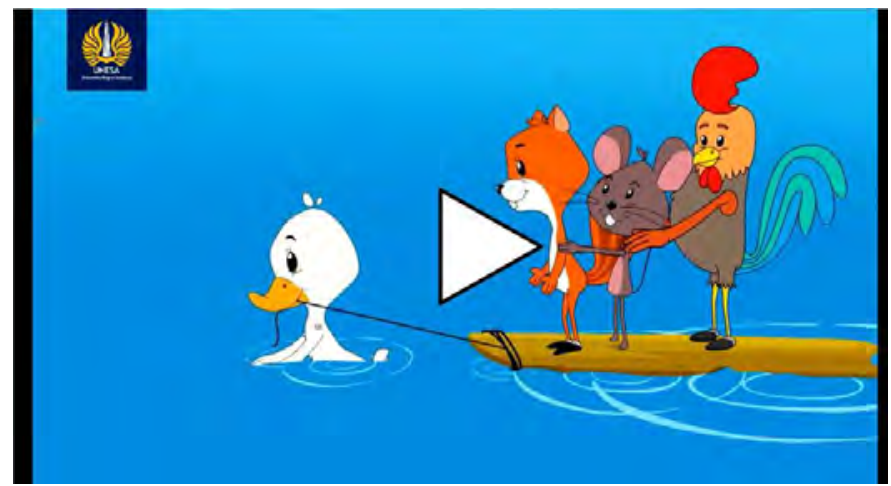

Fig. 2. Digital Storytelling Video

\section{B. The Quality of Digital Media Storytelling with Paired Storytelling Model.}

\section{1) The Validity Of DST Media}

The validity of DST media is measured through the assessment of expert validators. 4 validator lecturers perform an assessment of 4 components namely, the material component, language, sound and image. The material component obtained $84 \%$ with eligible category. While the language component obtained $92 \%$ with very decent category. Furthermore, the sound component gained $90 \%$ with very decent category. Then, the image component gained $88 \%$ with very feasible category. It can be concluded that the percentage of total validation results by experts is very valid and can be tested in the field.

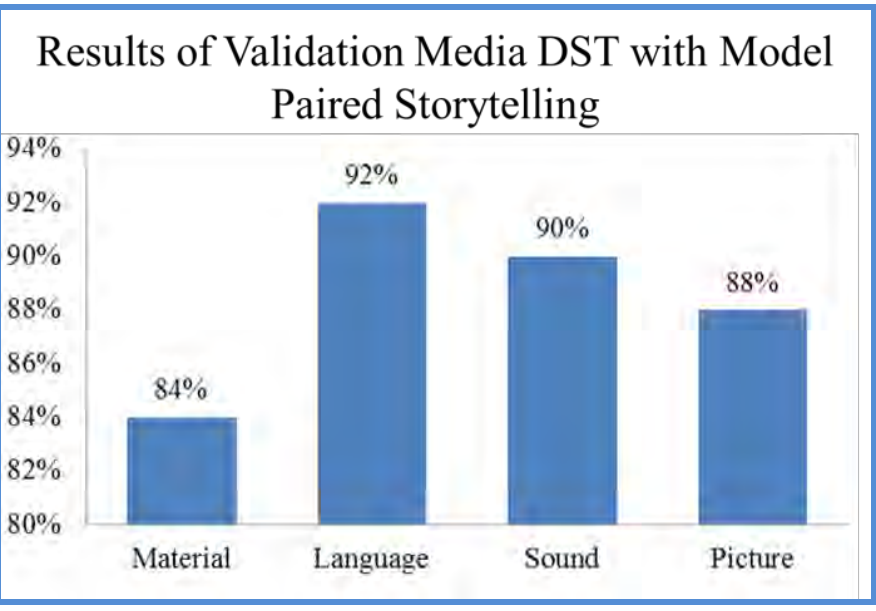

Fig. 3. Diagram of Validation DST Media Results with Paired Storytelling Model

\section{2) The Practicality Of DST Media}

The practicality of DST media applied using paired storytelling learning model is resolved through observation of RPP implementation, teacher's response, and students' response. The results of the implementation of RPP analysis were: the observation achieved a score of $87 \%$ with very good category; The teachers give a positive response by giving score $87 \%$. Likewise, the students responded positively with the acquisition of $94 \%$. therefore, in terms of practicality can be concluded that the DST media is very practical

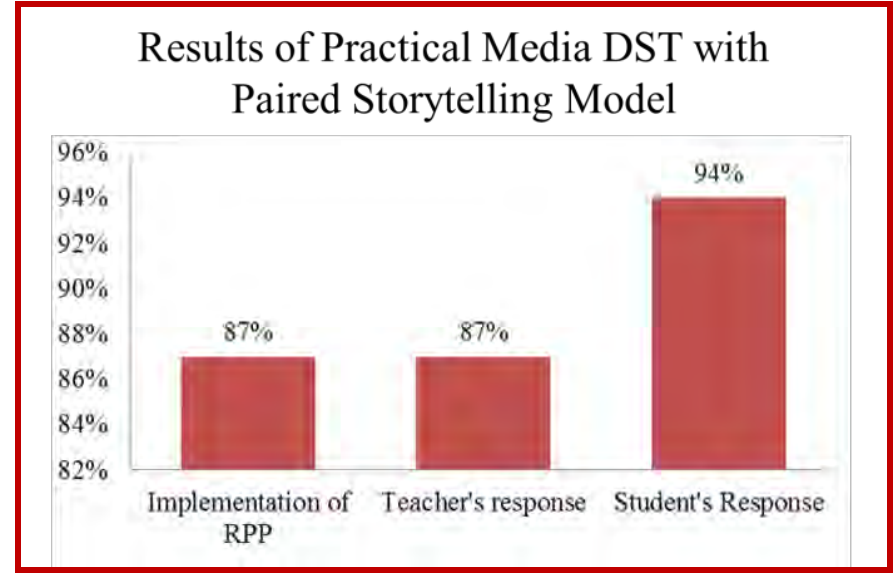

Fig. 4. Diagram of Practicial DST Media Results with Paired Storytelling Model

\section{3) The Effectiveness Of DST Media}

The effectiveness of DST media is measured through teacher's activity observation, student's activity enrichment and the mastery of speaking skills. Teacher's activity scored $85 \%$ with very good category. Student's activity showed a score of $88 \%$ with good category. Meanwhile, the completeness of the learning result shows the score 89 with classical thorough category. Therefore, in terms of effectiveness it can be concluded that DST media is very effective. 


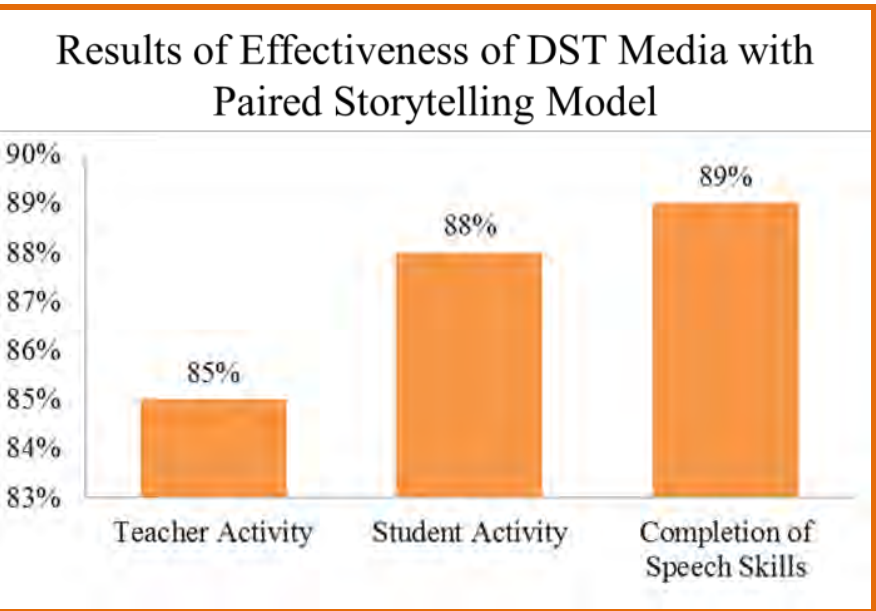

Fig. 5. Diagram of Effectiveness DST Media Results with Paired Storytelling Model

Based on data analysis of validity, practicality and effectiveness of DST media with paired storytelling model that has been tested the quality of DST media with the paired storytelling model can be seen in the following table. The table below shows the DST media quality with the paired storytelling model with the validity aspect is valid, the practical aspect is very practical, the aspect of effectiveness is very effective. Thus, it can be concluded that media DST media with paired storytelling model is highly qualified and worthy of use.

TABLE.1

Recapitulation of DST Media Quality Assessment Results with Paired Storytelling Model

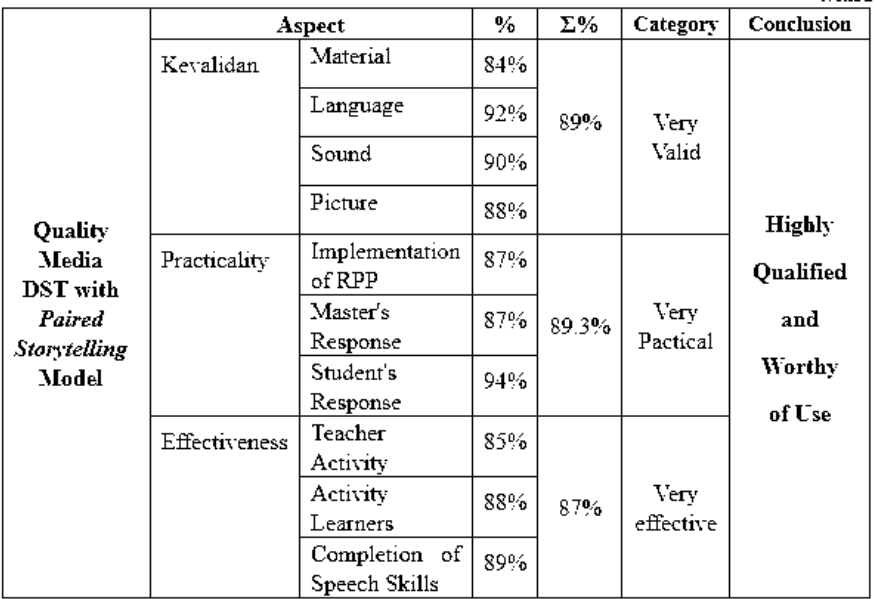

\section{CONCLUSION}

A. Digital Storytelling Media with Paired Storytelling Model Helps Teachers in Improving Student Speaking Skills

DST media with paired storytelling model can help students improve their speaking skills. The research was conducted in the class II SD Islam Annur Surabaya. The improvement of students' speaking skills can be seen from the pretest and posttest results during limited trials and extensive trials. The results of pretest and posttest on limited trials using DST draft media III obtained a mean score of pre-tests 54.06, while the mean score of the post-test result was 86.6. The classical pretest obtained $54 \%$ that included in the less good category. While the posttest obtained $87 \%$ classical completeness that included in the category very good.

Then the pretest result on a wide trial of 25 students obtained the average score 70.69 whereas the average posttest result is 90.3. Exhaustiveness of classical pretest $70 \%$ and declared not yet completed by classical. While the posttest acquired $90 \%$ classical completeness. The results of students' speaking skills have improved between pretest and posttest results either on a limited trial or extensive trial. The improvement is in accordance with learning theory proposed by Suyono and Hariyono (2011: 9) that learning is an activity or a process to acquire knowledge, improve, skills, improve behavior, attitude, and strengthen personality.

The results of this study are also similar to the results of Yoga Hermawan research (2016) entitled "Application of Paired Storytelling Model Assisted Audio Visual Media to Improve Speaking Skills in Indonesian Subjects" This research was conducted in two cycles.

The results of the research in cycle I showed that the average classical speaking skill of students reached 78.5 and classical completeness reached $64.7 \%$. In cycle II the average of classical speaking skill reached 87,2 and classical completeness reached $82,4 \%$. The data that have been obtained shows that there is an increase in speaking skill of grade $\mathrm{V}$ students in SD Negeri 4 Tejakula. Based on the above discussion it can be concluded that DST media with paired storytelling model can improve students' speaking skill.

\section{B. Digital Storytelling Media with Paired Storytelling Model Helps Teachers in Creating Active Students}

Student activity in learning is seen when teachers use DST media with paired storytelling model. Students are very enthusiastic when listening to the teacher's explanations, students are also listening actively when DST video is played, it can be seen from their response, smile or laugh when hearing funny things being delivered, amazed to hear something amazing. Students are also seen noting keywords or important things when listening to DST video. Students are very excited when requested by the teacher to recount the results to the group. In the discussion they look very happy because the teachers are rarely form groups discussion in learning.

Students can tell the story in front of the class with confidence, even they also express their opinions about the learning that has been followed. According to students' responses the DST media and paired storytelling model is very interesting. This is the evident of the results of student activity on a limited trial taht reached a score of $87 \%$. While on a wide trial reached $88 \%$. 
Based on the observation of students' activity during the learning process that observed by two teachers, it was found that the students' activity was influenced by several things, namely: 1) clear, unambiguous and fun teaching 2) the learning activities that involving students to take an active role, and 3) The use of DST media with paired storytelling model is very different from the learning that is usually done by the teacher. Creating an active and conducive class will require the role of teachers who master the class and creatively develop the media.

\section{Suggestion}

Based on the results of research and some facts encountered in the field, the researchers give some suggestions as follows.

1) Teachers can use DST media with this paired storytelling model as an alternative source of learning material of fable story to improve the skills of storytelling. However, in the implementation, it still needs to be adjusted to the school's situation and condition.

2) The principal and the education office should facilitate the teachers to develop the quality of instructional media in accordance with the 2013 curriculum in order to improve the quality of English language learning in Indonesia.

3) Due to the limited time, the dissemination stage of the 4$\mathrm{D}$ model is unable to be applied in this research. Therefore, the further research will apply this stage to gain more efficient result of the implementation of DST media.

\section{References}

[1] Anita, Lie. Mempraktikkan Cooperative Learning di Ruang Ruang Kelas. (Jakarta: Gramedia). 2010.

[2] Ariestyawati, Rina. Peningkatan Keterampilan Berbicara Menggunakan Media Audiovisual Pada Siswa Kelas II. Jurusan PGMI FITK. Malang, Universitas Negeri Malang. 2013.
[3] Frazel, Midge. Digital Storytelling: Guide for Educators.Washington DC: International Society for Technology in Education (ISTE), 2010.

[4] Heinich, R., Molenda. Et.al. Intructional Media and The New Technologies of Instruction. New York: Macmilan Publishing Company. 1993

[5] Hermawan, Yoga. Penerapan Model Pembelajaran Paired Storytelling Untuk Meningkatkan Keterampilan Berbicara pada Mata Pelajaran Bahasa Indonesia. Jurusan PGSD, FIP. Universitas Pendidikan Ganesha Singaraja, Indonesia. 2016

[6] Lambert, Joe. Digital Storytelling Capturing Lives, Creating Community. 4 th edition. New York: Routledge. 2013.

[7] Landis, et.al. "Digital Storytelling: A Tool for Teaching and Learning in The Youtube Generation". Middle School Journal, Vol. 42, No. 5 (May 2011), pp.4-10, tersedia di www.jstor.org. 2011.

[8] Pribadi, Benny. Media dan Teknologi dalam Pembelajaran. Jakarta: Dian Rakyat. 2017.

[9] Rule, Leslie.Digital Storytelling Association. Dalam http://edutechwiki.unige.ch/en/Digital_storytelling, 2007

[10] Suhartono. Kesenjangan Desain Pembelajaran Teks Sastra Dalam Praktik Pembelajaran Berbasis Teks: Studi Pada Aktivitas Siswa. Surabaya: FBS Universitas Negeri Surabaya. Prosiding Seminar Nasional Paramasastra 4. 2016

[11] Tarigan, Henry Guntur, Berbicara Sebagai Suatu Keterampilan Berbicara. Bandung : Angkasa. 2008

[12] Thomkins, G.E. \& Hoskinsson. K. Language Art Content and Teaching Strategis. New York: Macmillan Collage Publishing Company. 2006

[13] Xu, et.al. "A New Approach Toward Digital Storytelling: An Activity Focused on Writing Self-efficacy in a Virtual LearningEnvironment". Educational Technology \& Society, 14 (4), 181-191. 2011

[14] J. Clerk Maxwell, A Treatise on Electricity and Magnetism, 3rd ed., vol. 2. Oxford: Clarendon, 1892

[15] I.S. Jacobs and C.P. Bean, "Fine particles, thin films and exchange anisotropy," in Magnetism, vol. III, G.T. Rado and H. Suhl, Eds. New York: Academic, pp. 271-350, 1963

[16] K. Elissa, "Title of paper if known," unpublished. 2006

[17] R. Nicole, "Title of paper with only first word capitalized," J. Name Stand. Abbrev., in press. 2007

[18] Y. Yorozu, M. Hirano, K. Oka, and Y. Tagawa, "Electron spectroscopy studies on magneto-optical media and plastic substrate interface," IEEE Transl. J. Magn. Japan, vol. 2, pp. 740-741, August 1987 [Digests 9th Annual Conf. Magnetics Japan, p. 301, 1982

[19] M. Young, The Technical Writer's Handbook. Mill Valley, CA: University Science, 1989 